lja kršćanskog vulgarizma. Etnoreligijanska utvara u suvremenom sekularističkom društvu«, dovodi u pitanje nužnost sprege političkoga, etničkoga i religijskoga. Vulgarizirana inačica religije u religijanstvu, kao i politike u politikantstvu uistinu potrebuje intelektualnu kritiku i tu je Sekulić ispravno pronašao tematiku svoje kritike, ali ne možemo reći kako ju je uvjerljivo i adekvatno izveo. Sekulić vlastitu poziciju imenuje aktivističkom, što pruža dobar hermeneutički ključ za iščitavanje čitavoga njegovog teksta. Kršćanska teologija, kako ju Moltmann shvaća, uistinu ima potencijal u sebi za političko oslobođenje pojedinca, ali i za oslobođenje Crkve od politike. Upravo zato nužno je fokus preusmjeriti prema eshatološkoj dimenziji uskrsloga živoga Boga, a ne neprestano boraviti oko groba onoga Raspetoga. Križ je prije svega simbol uskrsnuća i života, a ne samo smrti i patnje. Radikalnost kršćanstva počiva u tome da se nužno mora izaći iz Kristova groba i proglasiti kako je on uskrsnuli i živi Bog, čime se temelji nade, koja ima sposobnost preobražavati svijet, uistinu polažu.

»Društvo kroz istinsku religioznost Crkve može oživotvoriti bogatstvo i smisao svog postojanja, a religioznost Crkve pak mora biti vođena konstruktivnom kritikom svakodnevnih socijalnih zbivanja kako bi obje ove stavke bile ispunjenjem, a ne degradacijom u životu jednog čovjeka, koji je, usput budi rečeno, fundamentalni uzorak na kojem se gradi kako građanski sustav humanističkog zaloga tako i teološki govor kršćanskog dijaloga« (str. 140)

Etnoreligijanstvo Sekulić otkriva u dvjema vrstama zaborava. Prvi je zaborav prema Bogu vlastita poziva, a drugi je zaborav prvenstveno teologijskog govora prema bližnjemu. Uistinu treba kritizirati fenomen uzdizanja vladajućih struktura nad onima kojima vladaju, slijedeći protučovječne tendencije svjetskih centara moći vođenih isključivo potrebama financijskog kapitala. Kada se religijske strukture priklanjanju zaštiti takvih struktura vlastitim duhovnim autoritetom, tada nastaje i potreba kritike postupaka vladajućih slojeva religijskih zajednica. U svojoj je knjizi Sol zemlje: kršćanstvo i Katolička crkva na prijelazu tisućljeća to Joseph Ratzinger imenovao patologijom kršćanskog nauka, a s tom Ratzingerovom dijagnozom bi se vjerujemo složio, iako nevoljko, i sam Moltmann. Upozorenje kršćanima, ali i svim ljudima koji nastoje živjeti religiozno, protiv takvih tendencija uobličeno je u Kristovim evanđeoskim riječima.

»U ono vrijeme Isus reče svojim učenicima: 'Vi ste sol zemlje. Ali ako sol obljutavi, čime će se ona osoliti? Nije više ni za što, nego da se baci van i da ljudi po njoj gaze. Vi ste svjetlost svijeta. Ne može se sakriti grad što leži na gori. Niti se užiže svjetiljka da se stavi pod posudu, nego na svijećnjak da svijetli svima u kući. Tako neka svijetli vaša svjetlost pred ljudima da vide vaša dobra djela i slave Oca vašega koji je na nebesima'.« (Mt, 5,13-16)

\section{Ivan Smiljanić}

doi: $10.21464 /$ fi38018

\section{Slobodan Sadžakoy}

\section{Egoizam}

\section{Etička studija o moralnim principima kapitalizma} $\frac{\text { Mediterran Publishing, }}{\text { Novi Sad } 2013 .}$

Izdana nepunih dvije godine nakon obrane doktorske disertacije pod nazivom $»$ Egoizam kao etičko-praktički problem«, knjiga Egoizam - etička studija o moralnim principima kapitalizma Slobodana Sadžakova predstavlja njenu proširenu i izmijenjenu verziju, na 255 stranica.

Osnovni je sadržaj knjige obrada pojma egoizma kao suprotnosti altruizmu (poglavlje »Altruizam - Entoni Šeftsberi« posvećeno je toj problematici) i njegove implementiranosti u modernoj društvenosti koja čini, između ostaloga, temelj prelaska iz feudalnog u kapitalistički sistem. Iako je pojam egoizma poznat u svakodnevnom govoru i to kao pojam koji je označen kao samoljublje, usmjerenost na samoga sebe, osobne interese i održanje, knjiga se bavi dubljom analizom i problematikom pojma egoizma na način da se »provlači« kroz prizmu raznih znanstvenih disciplina i njenih teorija; psihologije, sociologije, ekonomije, a pritom autor koristi bogat izvor literature raznih znanstvenih disciplina. Sam autor $\mathrm{u}$ uvodnom poglavlju »Egoizam kao etičko-praktički problem« za pojam egoizma kaže kako se on »najčešće spominje u kontekstu vrednovanja (ocjenjivanja) vlastitih ili tuđih postupaka koji pripadaju raznim formama društveno-praktičkog života« (str. 11) te ima važno mjesto $\mathrm{u}$ interpersonalnim odnosima. Unutar tih odnosa postoji međusobno »ocjenjivanje« koje je moralnog tipa te time egoizam zadobiva moralnu instancu. Time osobe koje bivaju okarakterizirane kao egoistične zadobivaju stigmu bezosjećajnih ljudi, 
nezainteresiranih za druge, a zainteresiranost za druge ljude zapravo je samo instrumentalan način za dolazak do osobnog cilja. U samom korijenu pojma egoizam jest latinska riječ ego koja označava neku pojedinačnost i posebnost koja se razlikuje od onog drugog. Taj ego, odnosno »Ja«, središnji je problem teorijske i praktičke filozofije identiteta.

Knjiga ponajviše istražuje praktičko-etičku refleksiju pojma egoizma u društvu u periodu od 16. do 19. stoljeća. Počevši od protestantske reforme pa sve do industrijalizma, knjiga prati najznačajnije autore koji su se bavili problematikom svojeg doba u različitim sferama i u kojima se može iščitati odnos pojedinac-Crkva, pojedinac-pojedinac i, naposljetku, pojedinac-društvo. Ujedno se prikazuje, takoreći, utjecaj makrokozmosa na mikrokozmos i obratno, tj. kako okolina utječe na pojedinca i kako taj pojedinac respondira na okolinu u kojoj se nalazi. Autor u knjizi spominje kako je u okviru toga potrebna »važna refleksija epohalnog procesa oslobođenja potencijala individualnosti« (str. 19) te kako je potrebno ispitati tezu o tome da se »egoizam razvijao na epohalnoj osnovi procesa individualizacije« (str. 20), koji je u povijesnom smislu započeo slamanjem feudalnog sustava. Takva teza može se ispitati osvrne li se pogled na Novi vijek i na nastanak kapitalizma u kojemu je potencijal moralnog opravdanja egoizma ostvaren.

S vremenskim odmakom, Descartesova filozofija odredila je početak novog vijeka i to tematizirajući mislećeg subjekta (pojedinca) kao nešto »Ja«, npr. »Ja« kao misleći subjekt mogu sumnjati u sve, osim u samu sumnju; »Ja« koje sumnja. Takav način tematiziranja dualizma, razlika između misleće i protežne supstance, omogućuje shvaćanje i utemeljenje individualnosti putem cogita kao misleće supstance. Leibnizov nastavak na Descartesa, svojom koncepcijom monada kao individualne supstance, dodatno utvrđuje razvoj za tematiziranje principa individualnosti. Odmakom od dominantnog kršćansko-skolastičkog učenja te razvojem kapitalizma u kojemu pojedinac zadobiva mogućnost individualnosti (razvojem osobnog identiteta), otvara se mogućnost gledanja ega iz druge perspektive; ne samo kao nešto što nam je utisnuto u prirodu nego kao nešto što bi u određenoj mjeri trebalo i njegovati. Važno je pritom napomenuti da knjiga nije pokušaj obrane ili napada na princip egoizma, nego pokušava utvrditi početak razvoja principa i njegovu manifestaciju u etičko-praktičkom diskursu:

»Naša osnovna intencija je da problem egoizma obradimo na filozofsko-etički način, slijedeći one interpretacijske paradigme koje su ovaj problem analizirale u njegovoj praktičkoj slojevitosti. Isticanje praktičke slojevitosti tog fenomena je od važnosti jer egoizam ni u realitetu nije nešto samo moralno konotirano te bi ga zato i bilo nepotpuno shvatiti izoliranog od cjeline praktičkog života, odnosno shvatiti samo kao etički problem.« (str. 26)

Upravo zato što u realitetu ima pravne, ekonomske, političke, socijalne i sl. aspekte, egoizam se kao problem proteže prema cjelini praktičke filozofije.

Knjiga je podijeljena na sedamnaest poglavlja i svako poglavlje predstavlja određeni period, tj. bavi se određenim filozofom tog perioda $i$ njegovom temom koja se u širem smislu bavi pojmom individualnosti, a pritom pripomaže u shvaćanju problematike ega odnosno egoizma. S obzirom na to da se istražuju principi egoizma i njegova promjena u moralno-etičkom vrednovanju, najbolji početak za takvu raspravu jest filozofija Martina Luthera i Jeana Calvina za vrijeme protestantske reforme jer »odgovori koje je ponudio protestantizam bili su u značajnom smislu korespondentni temeljnim povijesnim tendencijama tog vremena koje su vodile etabliranju kapitalizma« (str. 30). Nazvan »vijekom društvenih poremećaja «, u 16. st. nastaje reformacijski pokret i to u Njemačkoj gdje su povijesno-društvene (ne)prilike obilježile određeni stupanj zaostalosti spram npr. Nizozemske i Engleske gdje je feudalizam okončao prije negoli u Njemačkoj. Dugotrajna dominacija kršćanstva u duhovno-moralnom smislu bila je »poljuljana« reformacijom koja je donijela sukob unutar kršćanstva i narušila takav duhovno-moraln monopol koji je dominirao od strane katoličke crkve. Učenje (naročito novozavjetnog učenja koje osuđuje samoljublje, oholost $\mathrm{i}$ sebičnost) kakvo je zastupala katolička crkva bilo je duboko usađeno u feudalni sistem društvenosti. Svojim spisom »Kratko tumačenje Deset zapovijedi«, Luther reafirmira princip moralne individualizacije, što podrazumijeva »načelnu priznatost prava pojedinačne moralne namjere, moralnog uvjerenja, moralnog izbora itd., odnosno uvaženost mogućnosti samorukovodstva« (str. 34). Luther time naglašava »važnosti unutrašnjeg iskustva, vjere kao osobnog odnosa s bogom, što je isključivalo naglašeno institucionalizirano posredovanje« (ibid.). Pritom se ta individualnost treba isporučiti »van sebe«, u bogu kao transcendentnosti jer za Luthera je individualnost »sreća u bogu«. Calvin je, za razliku od Luthera, naglasio i važnost potvrđivanja u ekonomskoj sferi, iako u smislu djelatnog potvrđivanja ( $\mathrm{rad}$, kojeg Calvin shvaća individualnim) kao mogućnost povratka bogu. $\mathrm{Na}$ taj specifičan način Clavin je povezao sferu morala i ekonomije, a što je Luther izostavio.

Nadalje, razlaže se filozofija Niccola Machiavellija i Thomas Morea koji su u centar svojih 
istraživanja stavili razmatranje ljudske prirode, ne bi li se shvatilo kakav čovjek zapravo jest. Time se ideja o božanskoj utemeljenosti cjelokupnog života, zajedno s moralom, delegitimira. Naturalistička antropologija novog vijeka, u ovom slučaju u periodu od 16. do prve polovice 17. st., ključna je za razumijevanje egoizma. Jedan od pravaca tumačenja ljudske prirode bio je da je egoizam izraz ljudske prirode usmjerene na samoodržanje (Machiavelli i Hobbes); drugi pravac tumačenja ljudske prirode bio je trans-egoističan, što znači da se bit ljudske prirode ogleda u usmjerenost blagonaklonom ponašanju u odnosu na druge ljude (More i Shaftesbury). Pritom, oba pravca imaju zajedničku točku, a to je gledanje na realnog »empirijskog« čovjeka kao egoističko biće. Machiavellijevo shvaćanje čovjeka kao izvorno zlog i lošeg činilo je osnovu zasnivanja »realistične teorije države«. Svijest o pokvarenosti ljudske prirode omogućuje vladaru njegove vrline jer zna kako voditi državu i ljude koji su dio te države. Machiavellijevo naturalističko polazište predstavlja »revoluciju« u praktičkom djelovanju koje je važno za razvitak principa egoizma. Thomas More smatra da čovjek nije zao po prirodi, nego da je njegova zloća produkt društvenog ustrojstva. Ujedno, privatno vlasništvo je to koje čovjeka čini egoističnim i smatra da zajedničko vlasništvo donosi opće blagostanje.

Naturalistička antropologija neizostavna je kod kontraktualističkog trojca 17. i 18. stoljeća, Hobbes-Locke-Rousseau, koji su imali teoriju čovjekovog prirodnog stanja te čovjekov prijelaz iz prirodnog stanja $u$ društvo putem ideje ugovora. U tom periodu dolazi do snažnijeg etabliranja formi kapitalističke društvenosti.

Kod Hobbesa, egoizam je samo izraz ljudske prirodnosti (potreba za samoodržanjem), s obzirom na to da u prirodnom stanju čovjeka vlada zakon samoodržanja - rat svih protiv sviju. Lockea su nakon smrti prozvali »ocem europskog liberalizma« te ideologom liberalne demokracije i kapitalističkog društva jer je opravdavao duh svojeg vremena, tj. interese građanske klase. Bio je Hobbesov nasljednik, pritom je modificirao njegove ideje i uskladio ih s tradicijom. Pitanje o individualizmu otvorio je legitimirajući ga, »smatrajući da je pojedinac u osnovi samorukovodeći subjekt koji se suvereno potvrđuje u praktičkim formama života« (str. 84). Kao i Hobbes, Locke smatra da je čovjeku prva i najjača želja za samoodržavanjem. Pritom, izlazak iz prirodnog stanja kod Lockea je motiviran ne samo željom za samoodržanjem u smislu pukog života nego i za očuvanjem vlasništva. Za razliku od Hobbesa, smatra kako je čovjek u prirodnom sta- nju gospodar ne samo svoje osobnosti nego i vlasništva te smatra da ne vlada permanentno stanje rata i stanje u kojemu isključivo vladaju samovolja i sebičnost. Locke time naglašava važnost ekonomskog aspekta kod individue, gdje se individua moralno potvrđuje upravo kroz vlasništvo. Kako Hobbes, tako i Locke zapravo smatra da je čovjek racionalni egoist:

»On, slično Hobbesu, tvrdi da prirodnost upojedinjuje, da ljude pokreće ono nagonsko, odnosno raznovrsne želje nekada toliko jake da moraju biti obuzdane. Utemeljen u vlasništvu, kao primarnom polju svog ospoljenja, čovjek je prinuđen da u stalnoj napetosti gradi socijalne veze s drugim ljudima. Jedna od formi praktičkog posredovanja je i moral koji se, između ostalog, shvaća i kao način regulacije pretjeranih želja i egoizma.« (str. 91)

Rousseau pak gradi kritiku građanskog društva i ekonomskog ponašanja te je time postavio teorijske temelje za Francusku revoluciju stanovištem volonté générale. Rousseau smatra da se čovjek u prirodnom stanju rađa jednak, pritom ulazi u nejednakost putem civilizacije te $\mathrm{u}$ tom prirodnom stanju nema govora o moralnim određenjima, svojini, pravde/nepravde. Razlikovanje toga postaje tek izlaskom iz prirodnog stanja i ulaskom u društveni život. Prvi takav oblik nejednakosti među ljudima pojavljuje se nastankom vlasništva (nejednakost bogatih i siromašnih). Ipak, ono što je najvažnije kod Rousseaua jest to da on smatra kako se »čovjekova stvarnost neprestano modificira povijesnim kretanjem te se tako javljaju nove želje i motivi, odnosno karakterne crte. Drugim riječima, Rousseau sugerira da ljudska priroda kao takva nema svoje apsolutno 'fiksirane' odredbe« (str. 160).

Pored njih, u knjizi su neizostavni bili filozofi poput Anthonyja Shaftesburyja i njegove teorije altruizma kao suprotnost egoizmu, te Bernarda Mandevillea kao odgovora na Shaftesburyjevu postavku o tome kako je čovjek po prirodi altruističan - polazi od pojedinačne prirode pokrenute egoizmom te se na temelju pojedinačnih egoizama izvodi ono opće (praktički realitet). Nadalje se navodi David Hume koji smatra kako je neegoistično djelovanje moguće samo $\mathrm{u}$ "privatnim« krugovima, tj. pojedinac je ograničen altruistično djelovati samo na one koje poznaje, prije svega na obitelj, a zatim prijatelje i poznanike. Dalje se obrađuju teorije Adama Smitha, Claudea Helvètiusa, Kanta, Hegela i naposljetku Marxa, kod kojih se tema o egoizmu prikazuje unutar već navedenih antropoloških, socijalnih, političkih i ekonomskih aspekata.

Ono što se može zaključiti o knjizi Slobodana Sadžakova jest to da je temu o egoizmu temeljito približio i objasnio, istaknuvši kon- 
tekst vremena i stvaranja pojedinih filozofa koji su na neki određeni način govorili o temi egoizma. U knjizi se nije zauzimao stav »za« ili »protiv«, nego se htjelo ukazati na strukturne karakteristike fenomena egoizma kroz epohalne promjene načina života, počevši od tranzicije iz feudalnog u kapitalistički sistem društvenosti, te kako se taj fenomen reflektirao na praktičko-moralni odnos među ljudima. Princip egoizma svakako je postao praktičko-moralna stvarnost modernog čovjeka u kojoj je pojedinac u konstantnom sukobu između osobnih potreba (moral) i potreba društva (ekonomija). Na kraju djela, Sadža- kov upućuje na važnost kritičkog stava etike kao praktičko-filozofske discipline prema građanskom društvu, tj. važnost objašnjavanja veze između moralne sfere i ekonomske sfere. Knjiga Egoizam - etička studija o moralnim principima kapitalizma može također poslužiti kao kvalitetna referenca za istraživanje sociološkog razvoja društva u periodu od 16. do 19. stoljeća, najviše zahvaljujući Sadžakovljevom obuhvaćanju uzročno-posljedičnih povijesnih veza koje su ujedno i dovele do rasprave o fenomenu egoizma.

\section{David Martić}

